1 Lack of regularity between letters impacts word recognition

2 performance

3

4 Sofie Beier *

5 The Royal Danish Academy of Fine Arts, School of Design, Copenhagen, Denmark

6

7 Jean-Baptiste Bernard

8 The Royal Danish Academy of Fine Arts, School of Design, Copenhagen, Denmark

9

$10 *$ Corresponding author:

11 Email: sbe@kadk.dk

12

13

14

15

16

17

18 
bioRxiv preprint doi: https://doi.org/10.1101/753038; this version posted August 30, 2019. The copyright holder for this preprint (which was

not certified by peer review) is the author/funder, who has granted bioRxiv a license to display the preprint in perpetuity. It is made available under aCC-BY 4.0 International license.

Font regularity in word recognition

19

20

21

22

23

24

25

26

27

28

29

30

31

32

33

34

35

36

37

38

39

Keywords

40

Abstract

Physical inter-letter dissimilarity has been suggested as a solution to increase perceptual differences between letter shapes and hence a solution to improve reading performance. However, the deleterious effects of font tuning suggest that low inter-letter regularity (due to the enhancement of specific letter features to make them more differentiable) may impair word recognition performance. The aim of the present investigation was 1) to validate our hypothesis that reducing inter-letter regularity impairs reading performance, as suggested by font tuning, and 2) to test whether some forms of non-regularities could impair visual word recognition more. To do so, we designed four new fonts. For each font we induced one type of increased perceptual difference: for the first font, the letters have longer extender length; for the second font, the letters have different slants; and for the third font, the letters have different font cases. We also designed a fourth font where letters differ on all three aspects (worst regularity across letters). Word recognition performance was measured for each of the four fonts in comparison to a traditional sans serif font (best regularity across letters) through a lexical decision task. Results showed a significant decrease in word recognition performance only for the fonts with mixed-case letters, suggesting that fonts with low regularity, such as mixed-case letters, should be avoided in the definition of new "optimal" fonts. Letter recognition performance measured for the five different fonts through a trigram recognition task showed that this effect is not consistently due to poor letter identification.

Peripheral vision, word recognition, letter recognition, reading, font tuning 
bioRxiv preprint doi: https://doi.org/10.1101/753038; this version posted August 30, 2019. The copyright holder for this preprint (which was

not certified by peer review) is the author/funder, who has granted bioRxiv a license to display the preprint in perpetuity. It is made available under aCC-BY 4.0 International license.

Lack of regularity between letters impacts word recognition

The often repeated saying among typographers that "type is a beautiful group of letters, not a group of beautiful letters" (1), suggests that it is only when letters work as a group that they become type, a visual characteristic that we name "inter-letter regularity". To achieve this, a basic principles of sign painting and font design dictates that fonts and lettering shall be based on a repetition of shapes with the aim of ensuring harmony and balance between the letters modular systems that put together constitute the alphabet (one for lowercase letters and one for uppercase letters) (4). Such an approach naturally leads to letters of relatively similar shapes (and high regularity). By contrast, it has often been proposed that greater letter distinctiveness, where new features are added to selected letters, could facilitate reading, as it minimizes the risk of letter confusion (5-7). However, greater letter distinctiveness also decreases inter-letter regularity.

To investigate whether high letter differentiation could improve peripheral reading,

61 Bernard et al. (7) created a new font, referred to as Eido (Fig 2). They found that while participants familiarized themselves with the font, their reading performance improved for 
bioRxiv preprint doi: https://doi.org/10.1101/753038; this version posted August 30, 2019. The copyright holder for this preprint (which was not certified by peer review) is the author/funder, who has granted bioRxiv a license to display the preprint in perpetuity. It is made available under aCC-BY 4.0 International license.

Font regularity in word recognition

63 both letter and word recognition, although sentence reading speed was not significantly

64 improved. Xiong et al. (8) further found that Eido outperformed both Helvetica and Times

Roman for reading acuity performance, while maximum reading speed was not significantly improved. Also interested in letter differentiation, Beier and Larson (9) measured letter recognition of variations within the same font family and found certain letter shapes of greater dissimilarity to facilitate better single letter recognition than others. of mixed upper- and lowercase letters; slant to left and right; and longer ascenders and descenders. when letters are put together to make words, even if readers are familiar with each of the individual letter templates. Eido letters look as if they belong to different fonts mixed together, as typographic nonsense. This is also important, since previous research has showed that although readers may improve their performance by reading fonts with uncommon letter shapes, they do not like to do so (10). It also suggests that without prior practice and familiarization with the font style, the lack of font tuning would have a negative effect on reading text set in Eido. In multiple cases, font tuning has been demonstrated in central vision (11-13). This phenomenon occurs when readers recognize a sequence of letters presented in the same font faster than when presented with a mix of fonts. The effect has been shown in search tasks when readers recognize a target letter among letters of the same font compared to a mix of font styles (13), or when lexical decision is positively affected by successively presented words being set in the same font compared to switching between fonts (Cooper 
bioRxiv preprint doi: https://doi.org/10.1101/753038; this version posted August 30, 2019. The copyright holder for this preprint (which was not certified by peer review) is the author/funder, who has granted bioRxiv a license to display the preprint in perpetuity. It is made available under aCC-BY 4.0 International license.

Font regularity in word recognition

87

88

89

and Bold) (15). The results are interpreted as an indication that the perceptual system processes text representation by identifying the specific structures of a font and then tunes into these features (16).

This notion of feature tuning has parallels with findings on words set in miXeD cAsE. The negative effect on recognition of mixed-cased words has been shown in multiple experiments investigating lexical decision (17) and sentence reading $(18,19)$. By employing a lexical decision paradigm with central visual presentation, recent research has demonstrated that this mixed-case effect is unrelated to the availability of lexico-sematic information and is instead due to a lack of visual familiarity (20). The findings on font tuning (mixed-fonts) and the findings on visual familiarity (mixed-case) all suggest that as a reader is presented with a word, the perceptual system relies on prior exposure to specific visual rule sets concerning how components within a word relate to each other.

In this paper we were interested in the effect of fonts of varying inter-letter regularity styles on word recognition performance. We tested the hypothesis that low inter-letter regularity can have a negative effect on peripheral word recognition performance and tested whether some specific forms of lacking inter-letter regularity are more deleterious than others.

\section{Font design}

We designed four new fonts that are all based on the traditional font DejaVu Sans. We took great care in developing versions where the letter shapes were of familiar structures. In other words, it was essential not to reinvent the alphabet in the aim for a high degree of letter differentiation. The categories were as follows: A) The Extended category has exceptionally long ascenders and descenders, the longer extenders increasing the dissimilarity between letters such as ' $n$ ' > ' $h$ ', and 'o' > 'p'. While so doing, we maintain the important modular 
bioRxiv preprint doi: https://doi.org/10.1101/753038; this version posted August 30, 2019. The copyright holder for this preprint (which was not certified by peer review) is the author/funder, who has granted bioRxiv a license to display the preprint in perpetuity. It is made available under aCC-BY 4.0 International license.

Font regularity in word recognition

110 system that typographers find essential for fluent reading (2). The modular system of the

111 Extended font results in good inter-letter regularity. B) The Slant category is made by rotating

112 letters to the left and right, while the letters maintain their internal relation. This rotation

113 breaks with the inter-letter regularity, as letter pairs such as ' $h$ ' and 'b' no longer have

114 common paths when superimposed. The lack of a modular system for the Slant font results in

115 poor inter-letter regularity. C) The MixedCase category, defined as a mix of lower- and

116 uppercase letters, is based on findings that mixed-case text has low visual familiarity (20), as

117 it breaks with all typographical rules concerning the repetition of shapes (in contrast to fonts

118 of good inter-letter regularity, 'b' and 'p' share no modules). The lack of a modular system for

119 the MixedCase font results in poor inter-letter regularity. Three of the fonts contain only one

120 visual category, while one contains all three categories (Fig 3).

121 All fonts were tested with the same x-height. The two fonts with long extenders (Collect

122 and Extend) were therefore presented in a larger total vertical size than the fonts with

123 regular-length extenders (Fig 4).

Fig 3. The fonts are based on the DejaVu Sans Mono font (a) and are all designed for the present investigation. The font family

includes the three categories: b) Extend with exceptionally long ascenders and descender, c) MixedCase with uppercase letter 
bioRxiv preprint doi: https://doi.org/10.1101/753038; this version posted August 30, 2019. The copyright holder for this preprint (which was

not certified by peer review) is the author/funder, who has granted bioRxiv a license to display the preprint in perpetuity. It is made available under aCC-BY 4.0 International license.

Font regularity in word recognition

134 We tested word recognition performance for each of the newly designed fonts and compared

135 it to a master font in a traditional design (DejaVu Sans).

\subsection{Subjects}

138 The six subjects who participated in the experiments all had self-reported normal or

139 corrected-to-normal vision. The subjects were aged 20 to 25 years (mean age 23 years), three

140 were females, and they were recruited through the website forsoegsperson.dk. Written

141 informed consent was obtained from the subjects after the nature of the study had been

142 explained to them. The research complied with the Declaration of Helsinki and The Danish

143 Code of Conduct for Research Integrity. All subjects received a gift card of DKK 300 upon

144 completion of the experiment.

\subsection{Apparatus}

147 Stimuli were displayed on a 17-inch IBM/Sony CRT monitor (refresh rate $=85 \mathrm{hz}$, resolution $=$ $1481024 \times 768$ ) connected to an ASUS laptop PC. Experiments were written using the software 149 OpenSesame (21).

150 The experiments were carried out in a darkened room with dim lighting. Subjects were 151 placed at a viewing distance of $50 \mathrm{~cm}$ from the screen. The stimuli were presented as white 152 text on a black background. 
bioRxiv preprint doi: https://doi.org/10.1101/753038; this version posted August 30, 2019. The copyright holder for this preprint (which was

not certified by peer review) is the author/funder, who has granted bioRxiv a license to display the preprint in perpetuity. It is made available under aCC-BY 4.0 International license.

Font regularity in word recognition

The 500 Danish words were Danish lemmas of four to six characters with a lexical frequency of 0.00002 to 0.03 percent of occurrences. The pseudowords were generated by changing one

157 letter of existing words; care was taken so the change resulted in a pseudoword and not a 158 new, actual word.

161 We compared word recognition performance for the different fonts through a lexical decision 162 task. Details of the experiment are shown in Fig 5.

163 The subject was asked to fixate on a central dot while words or pseudowords were 164 randomly presented at $10^{\circ}$ in the lower visual field. The experimenter kept a close watch on 165 the subject to control for steady fixation on the target dot. Trials that involved eye movements 166 were discarded. When the subject was ready for a trial, he or she pressed the down arrow on 167 the keyboard, after which the exposure occurred. To carry out the task, the subject had to 168 press the left or right arrow when he or she identified a word or a pseudoword. The session 169 lasted about two hours and consisted of nine blocks of 100 trials for each font. The blocks 170 were presented in random order. A total of 450 words and 450 pseudowords were presented. 
bioRxiv preprint doi: https://doi.org/10.1101/753038; this version posted August 30, 2019. The copyright holder for this preprint (which was not certified by peer review) is the author/funder, who has granted bioRxiv a license to display the preprint in perpetuity. It is made available under aCC-BY 4.0 International license.

Font regularity in word recognition

\subsection{Results, Experiment 1}

175 The results of the lexical decision task are shown in Fig 6. The DejaVu font shows the best

176 lexical decision performance on average across subjects (lexical decision time: $0.14 \pm 0.01 \log$ 177 ms - average \pm standard error). Collect had the worst lexical decision performance on average 178 (lexical decision time: $0.22 \pm 0.02 \log \mathrm{ms}$ ).

Fig 6. Average and standard error log response time (s) for the different fonts. P-values: $* * *<0.001, * *<0.01, *<0.05$.

The visible separation between the two groups of fonts (DejaVu, Extended and Slant vs.

MixedCase and Collect is significant, as shown by a linear mixed effect with log reaction time

Table 1.

\begin{tabular}{|l||l|l|l|l|l|}
\hline & DejaVu & Collect & Extended & Mixedcase & Slant \\
\hline \hline DejaVu & & $0.0020^{* *}$ & 0.4669 & $0.0055^{* *}$ & 0.8654 \\
\hline Collect & $0.0020^{* *}$ & & $0.0002^{* * *}$ & 0.7184 & $0.0014^{* *}$ \\
\hline Extended & 0.4669 & $0.0002^{* * *}$ & & $0.0008^{* * *}$ & 0.5832 \\
\hline MixedCase & $0.0055^{* * *}$ & 0.7184 & $0.0008^{* * *}$ & & $0.0042^{* *}$ \\
\hline Slant & 0.8654 & $0.0014^{* *}$ & 0.5832 & $0.0042^{* *}$ & \\
\hline
\end{tabular}


bioRxiv preprint doi: https://doi.org/10.1101/753038; this version posted August 30, 2019. The copyright holder for this preprint (which was not certified by peer review) is the author/funder, who has granted bioRxiv a license to display the preprint in perpetuity. It is made available under aCC-BY 4.0 International license.

Font regularity in word recognition

\subsection{Discussion, Experiment 1}

191 The font styles Extended and Slant both resulted in similar performances to that for DejaVu, with no statistical differences observed between the different fonts. While Extended has similar inter-letter regularity to DejaVu (both have well-functioning modular systems

194 between letter groups, such as e-c-o, p-b-q-d and u-n-m-h), the Slant font can be considered 195 less regular because its oblique features with multiple orientations are features that are rarely present in typical letters. The findings suggest that a poorer inter-letter regularity, which is

197 the result from slanting letters to the left and right, does not impede word recognition 198 performance. The same is not the case for the mixed-case fonts (MixedCase and Collect), 199 which exhibited large and significant negative difference from the others with regard to word 200 recognition performance. Mixed-case fonts are considered fonts with poor inter-letter 201 regularity, as they mix two different kinds of modular systems (lower- and uppercase 202 systems).

203 Based on our initial findings, we were interested in investigating letter recognition 204 performance for the same test fonts. We wanted to ensure that our results were due to 205 differences in inter-letter regularity, not lower-level factors, such as inter-letter confusability.

\section{Experiment 2. Peripheral letter identification}

207 With the same fonts and apparatus as in Experiment 1 we tested letter recognition when the 208 stimuli were presented to subjects in trigrams (three-letter strings).

\subsection{Subjects}

211 Eight new subjects participated in the experiment, all self-reporting normal or corrected-tonormal vision. The subjects were aged 21 to 29 years (mean age 25 years), seven were 
bioRxiv preprint doi: https://doi.org/10.1101/753038; this version posted August 30, 2019. The copyright holder for this preprint (which was not certified by peer review) is the author/funder, who has granted bioRxiv a license to display the preprint in perpetuity. It is made available under aCC-BY 4.0 International license.

Font regularity in word recognition

213 females. As in Experiment 1, written informed consent was obtained from the subjects after

214 the nature of the study had been explained to them. The research followed the tenets of the

215 Declaration of Helsinki and The Danish Code of Conduct for Research Integrity. All subjects

216 received a gift card of DKK 150 upon completion of the experiment.

The task was to recognize all the letters of a trigram that was briefly presented at $10^{\circ}$ in the lower visual field. Print size was chosen so that the recognition rate of the central letter was about $50 \%$ during a pre-trial training session of 10 trials per font. The presentation time was $200 \mathrm{~ms}$. Subjects were asked to fixate on a dot centred on the screen. The experimenter kept a close watch on the eyes of the subject to control for steady fixation on the target dot. Approximately 5\% of the trials were discarded because of eye movements. The principles of the experiment are shown in Fig 7. When the subject was ready for a trial, he or she pressed the space bar on a computer keyboard, after which the stimulus exposure occurred. Following the presentation, the subject was asked to select the three stimuli letters displayed during the trial from left to right. No feedback was given to the subject. The session lasted about one hour and consisted of six blocks of 100 trials each. To avoid participants becoming familiar with the letter shapes of the fonts, each block consisted of 20 consecutive trials for each font.

231 The font order was random for each block. For each trigram, three letters were randomly selected among the 26 letters of the alphabet. 
bioRxiv preprint doi: https://doi.org/10.1101/753038; this version posted August 30, 2019. The copyright holder for this preprint (which was not certified by peer review) is the author/funder, who has granted bioRxiv a license to display the preprint in perpetuity. It is made available under aCC-BY 4.0 International license.

Font regularity in word recognition

\subsection{Results, Experiment 2}

238 Fig 8 shows the average letter recognition rates per trigram presentation for each font.

239 Standard errors across subjects are indicated in the figure. The traditional DejaVu font has a

240 high recognition score (1.93 \pm 0.03 letters per trigram) and on average is only inferior to the

241 Extended font $(1.97 \pm 0.03$ letters per trigram). By contrast, the fonts with the poorest

242 recognition rates are the Collect, MixedCase and Slant fonts, which have an average

243 recognition rate between 1.79 and 1.89 letters per trigram, with the Slant font resulting in the 244 poorest performance.

Fig 8. Average number of identified letters and standard error values across subjects. P-values: $* * *<0.001, * *<0.01, *<0.05$.

We ran a mixed-effect model to test whether the differences observed between the fonts

were significant. The dependant variable was the number of letters correctly identified, the

fixed variables were the font types, and the random variable was the subject identity. P-values

\begin{tabular}{|l||c|c|c|c|c|}
\hline & DejaVu & Collect & Extended & MixedCase & Slant \\
\hline \hline DejaVu & & 0.35 & 0.37 & $0.049 *$ & $0.0006 * * *$ \\
\hline Collect & 0.35 & & $0.0678+$ & 0.3002 & $0.0131 *$ \\
\hline Extended & 0.37 & $0.0664+$ & & $0.0040 * *$ & $0.0000 * * *$ \\
\hline MixedCase & $0.049 *$ & 0.3002 & $0.0042 * *$ & & 0.1485 \\
\hline Slant & $0.0006 * * *$ & $0.0131 *$ & $0.0000 * * *$ & 0.1485 & \\
\hline
\end{tabular}


bioRxiv preprint doi: https://doi.org/10.1101/753038; this version posted August 30, 2019. The copyright holder for this preprint (which was not certified by peer review) is the author/funder, who has granted bioRxiv a license to display the preprint in perpetuity. It is made available under aCC-BY 4.0 International license.

Font regularity in word recognition

The p-values confirm that the DejaVu and the Extended fonts offer a significant advantage

in our peripheral letter recognition task. Statistically, Extended shows significantly better performance than the three other fonts. DejaVu is superior to two fonts, and Collect is superior to the Slant font.

Overall, the findings demonstrate that the results for letter recognition performance are very different compared to word recognition performance. More generally, the correlation between word and letter recognition performance is very poor $(\mathrm{R} 2=0.06)$.

\subsection{Discussion, Experiment 2}

The Extended, DejaVu and Collect fonts had significantly higher scores with regard to letter recognition performance, meaning that they had the lowest inter-letter confusability. The Slant font had the poorest letter recognition performance followed by the MixedCase font. When we compare this with the results of Experiment 1, it suggests that what we observed in

Experiment 1 (poorest performance for both fonts with mixed-case letters) cannot be due to a 270 poor inter-letter confusability but is directly linked to the lack of regularity between the 271 different letters.

\section{General discussion}

273 Our first hypothesis was that poor inter-letter regularity would impair reading performance.

274 Our results suggest that, indeed, lack of inter-letter regularity can significantly impair 275 peripheral word recognition performance. We showed this negative effect for two fonts 276 (MixedCase and Collect), both mixing lowercase and uppercase letters. These fonts with the 277 smallest inter-letter regularity (due to being a mix of lower- and uppercase modular systems) 
bioRxiv preprint doi: https://doi.org/10.1101/753038; this version posted August 30, 2019. The copyright holder for this preprint (which was not certified by peer review) is the author/funder, who has granted bioRxiv a license to display the preprint in perpetuity. It is made available under aCC-BY 4.0 International license.

Font regularity in word recognition

278

279

280

were also the fonts that significantly resulted in the poorest performances, while the fonts that had a better inter-letter regularity (DejaVu and Extended) resulted in the best performances. Interestingly, intermediary irregularity caused by tilted letters (Slant) did not significantly affect word recognition performance.

The findings of the word recognition experiment cannot be explained by letter recognition performances, as results were inconsistent between the two experiments. In the case of the Slant font, the findings show opposite results between letter and word recognition. The Slant font was the poorest-performing font with regard to letter recognition, while for word recognition it showed a similar recognition rate to the two best-performing fonts and did significantly better than the two mixed-case fonts. Our findings thus show an important limitation of the usually accepted theory that links peripheral letter and word recognition performance $(22,23)$. It is also possible that the lack of regularity between letters causes the disruption of word uniformity, and a consecutive decrease in word recognition performance (24).

The letters in the slant conditions were either rotated to the right or to the left or had no rotation. It appears that for letter recognition, this rotation is confusing, as it is difficult to predict the nature of the rotation for each single letter. While for word recognition, the rhythm produced by the rotations of the Slant font condition leads to greater predictability of the word components and thus makes it easier for the subjects to tune into the font structure. Our results differ from findings by Gauthier et al. (13), who compared recognition of letter trigrams where the letters were slanted to one side to the recognition of trigrams where the letters were mixed between slants to the left and right (similar to our Slant font) and found no difference in performance between the two font conditions. Since our experiment did not 
bioRxiv preprint doi: https://doi.org/10.1101/753038; this version posted August 30, 2019. The copyright holder for this preprint (which was not certified by peer review) is the author/funder, who has granted bioRxiv a license to display the preprint in perpetuity. It is made available under aCC-BY 4.0 International license.

Font regularity in word recognition

compare the Slant font with a font condition that only had a slant to one side, this may be the cause of the different results.

The fact that the mixed-case fonts (Collect and MixedCase) are the poorest-performing in

the word recognition experiment confirms previous studies of the mixed-cased effect on foveal recognition (17-20). In the present study, we extend the findings to include peripheral vision.

features was significantly outperformed by DejaVu, which indicates that the negative influence of mixed-case fonts on letter recognition is less pronounced than the impact on to word recognition. If letters within a word become too uncommon in relation to each other, subjects may have to adopt a reading strategy based on serial processing of each single letter, which is much less efficient than parallel processing drawing on orthographic lexical information $(25,26)$.

For both letter and word recognition, the long extenders hold an advantage (Extended). In reading situations involving smaller visual angles, a large x-height (meaning shorter extenders) is known to facilitate reading (27). However, it is possible that if the $\mathrm{x}$-height is kept constant, longer extenders could also benefit reading at small visual angles. Our findings suggest that for reading situations involving peripheral reading, long ascenders and

319 descenders may be an advantage. This is interesting, since, to our knowledge, this simple 320 change in fonts had never been directly tested, although it seems to be an easy way to modify 321 a font and improve letter recognition performance.

Studies into letter recognition suggest that letters are recognized by their features $(6,28$ -

323 30). Viewing our findings in this perspective, the data on letter recognition suggests that as 
bioRxiv preprint doi: https://doi.org/10.1101/753038; this version posted August 30, 2019. The copyright holder for this preprint (which was not certified by peer review) is the author/funder, who has granted bioRxiv a license to display the preprint in perpetuity. It is made available under aCC-BY 4.0 International license.

Font regularity in word recognition

325 importance. In contrast to this, the data on word recognition suggests that word processing

326 benefits from regularity. It is generally believed that for successful word processing, it is

327 highly essential to be able to recognize the letters and their features $(26,31,32)$; our findings 328 add to this by demonstrating that in addition to great inter-letter dissimilarity (7), inter-letter 329 regularity within a word also contributes to successful word recognition.

We found evidence that a new factor, which we have labelled regularity, has a direct effect on word recognition performance, as fonts of great inter-letter regularity outperformed fonts of low inter-letter regularity in a peripheral word recognition task. The effect varied between letter and word recognition, so that rotated familiar letter shapes had a more negative effect on letter recognition than on word recognition, and mixing upper- and lowercase letters which was generally detrimental - had a more negative effect on word recognition than on letter recognition. Our key finding is that between letter and word recognition, great interletter regularity has the most positive effect on word recognition and less on letter recognition, which shows that supplementary features can improve letter recognition, while

341 they have a negative effect on word recognition. Our findings demonstrate that the typographic approach of working with inter-letter regularity is an important factor that needs to be considered in the design of fonts for word processing in peripheral vision.

\section{Acknowledgments}

We are grateful to the Society for Danish Language and Literature for creating a list of orthographic neighborhood sizes for Danish words and a list of the most common lemmas, 
bioRxiv preprint doi: https://doi.org/10.1101/753038; this version posted August 30, 2019. The copyright holder for this preprint (which was not certified by peer review) is the author/funder, who has granted bioRxiv a license to display the preprint in perpetuity. It is made available under aCC-BY 4.0 International license.

Font regularity in word recognition

348

which is based on the all the entries in the Danish Dictionary. This work was supported by the Danish Council for Independent Research [grant number DFF - 7013-00039].

\section{References}

1. Carter M. An Exercise in Versatility. In: Cabarga L, editor. Logo, Font \& Lettering Bible: A comprehensive guide to the design, construction and usage of alphabets, letters and symbols: Davis \& Charles; 2004. p. 200.

2. Beier S. Type Tricks: Your Persomal Guide to Typedesign: BIS Publishers; 2017.

3. Gates D. Lettering for Reproduction. New York: Watson-Guptill Publications; 1969.

4. Blokland FE, der Kunsten A. On the origin of patterning in movable Latin type: Renaissance standardisation, systematisation, and unitisation of textura and roman type 2016.

5. Beier S. Reading Letters: designing for legibility: BIS Publishers; 2012.

6. Fiset D, Blais C, Ethier-Majcher C, Arguin M, Bub D, Gosselin F. Features for identification of uppercase and lowercase letters. Psychological science. 2008;19(11):1161-8.

7. Bernard J-B, Aguilar C, Castet E. A New Font, Specifically Designed for Peripheral Vision, Improves Peripheral Letter and Word Recognition, but Not Eye-Mediated Reading Performance. PloS one. 2016;11(4):e0152506.

8. Xiong Y-Z, Lorsung EA, Mansfield JS, Bigelow C, Legge GE. Fonts designed for macular degeneration: Impact on reading. Investigative ophthalmology \& visual science. 2018;59(10):41829.

9. Beier S, Larson K. Design improvements for frequently misrecognized letters. Information Design Journal. 2010;18(2):118-37.

10. Beier S, Larson K. How does typeface familiarity affect reading performance and reader preference? Information Design Journal. 2013;20(1):16-31.

11. Sanocki T. Visual knowledge underlying letter perception: Font-specific, schematic tuning. Journal of Experimental Psychology: Human Perception and Performance. 1987;13(2):267.

12. Sanocki T. Font regularity constraints on the process of letter recognition. Journal of Experimental Psychology: Human Perception and Performance. 1988;14(3):472.

13. Gauthier I, Wong AC, Hayward WG, Cheung OS. Font tuning associated with expertise in letter perception. Perception. 2006;35(4):541-59. 
bioRxiv preprint doi: https://doi.org/10.1101/753038; this version posted August 30, 2019. The copyright holder for this preprint (which was not certified by peer review) is the author/funder, who has granted bioRxiv a license to display the preprint in perpetuity. It is made available under aCC-BY 4.0 International license.

Font regularity in word recognition

378

379

380

381

382

14. Walker P. Font tuning: A review and new experimental evidence. Visual Cognition. 2008;16(8):1022-58.

15. Dyson MC, Beier S. Investigating typographic differentiation: Italics are more subtle than bold for emphasis. Information Design Journal. 2016;22(1):3-18.

16. Sanocki T, Dyson MC. Letter processing and font information during reading: Beyond distinctiveness, where vision meets design. Attention, Perception, \& Psychophysics. 2012;74(1):132-45.

17. Allen PA, Wallace B, Weber TA. Influence of case type, word frequency, and exposure duration on visual word recognition. Journal of Experimental Psychology: Human Perception and Performance. 1995;21(4):914.

18. Reingold EM, Rayner K. Examining the word identification stages hypothesized by the EZ Reader model. Psychological science. 2006;17(9):742-6.

19. Reingold EM, Yang J, Rayner K. The time course of word frequency and case alternation effects on fixation times in reading: Evidence for lexical control of eye movements. Journal of Experimental Psychology: Human Perception and Performance. 2010;36(6):1677.

20. Perea M, Fernández-López M, Marcet A. Does CaSe-MiXinG disrupt the access to lexico-semantic information? Psychological research. 2018:1-9.

21. Mathôt S, Schreij D, Theeuwes J. OpenSesame: An open-source, graphical experiment builder for the social sciences. Behavior research methods. 2012;44(2):314-24.

22. Bernard J-B, Castet E. The optimal use of non-optimal letter information in foveal and parafoveal word recognition. Vision research. 2019;155:44-61.

23. Legge GE, Cheung S-H, Yu D, Chung ST, Lee H-W, Owens DP. The case for the visual span as a sensory bottleneck in reading. Journal of vision. 2007;7(2):9-.

24. Rummens K, Sayim B. Disrupting uniformity: Feature contrasts that reduce crowding interfere with peripheral word recognition. Vision research. 2019;161:25-35.

25. Houpt JW, Townsend JT, Donkin C. A new perspective on visual word processing efficiency. Acta psychologica. 2014;145:118-27.

26. Coltheart M, Rastle K, Perry C, Langdon R, Ziegler J. DRC: A dual route cascaded model of visual word recognition and reading aloud. Psychological review. 2001;108(1):204-56.

27. McCarthy MS, Mothersbaugh DL. Effects of typographic factors in advertising-based persuasion: A general model and initial empirical tests. Psychology \& Marketing. 2002;19(7-8):66391.

28. Petit J-P, Grainger J. Masked partial priming of letter perception. Visual Cognition. 2002;9(3):337-53. 
bioRxiv preprint doi: https://doi.org/10.1101/753038; this version posted August 30, 2019. The copyright holder for this preprint (which was

not certified by peer review) is the author/funder, who has granted bioRxiv a license to display the preprint in perpetuity. It is made available under aCC-BY 4.0 International license.

Font regularity in word recognition

412 29. Rosa E, Perea M, Enneson P. The role of letter features in visual-word recognition:

413 Evidence from a delayed segment technique. Acta psychologica. 2016;169:133-42.

$414 \quad$ 30. Lanthier SN, Risko EF, Stolz JA, Besner D. Not all visual features are created equal:

415 Early processing in letter and word recognition. Psychonomic bulletin \& review. 2009;16(1):67-73.

$416 \quad 31 . \quad$ Perry C, Ziegler JC, Zorzi M. When silent letters say more than a thousand words: An 417 implementation and evaluation of CDP++ in French. Journal of Memory and Language.

$418 \quad 2014 ; 72: 98-115$.

$419 \quad$ 32. Pelli DG, Farell B, Moore DC. The remarkable inefficiency of word recognition.

420 Nature. 2003;423(6941):752-6.

421 
Fig 1 


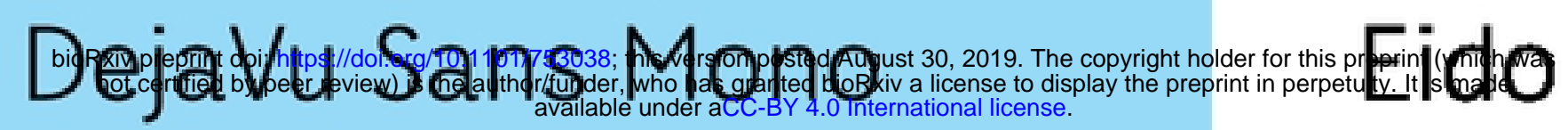
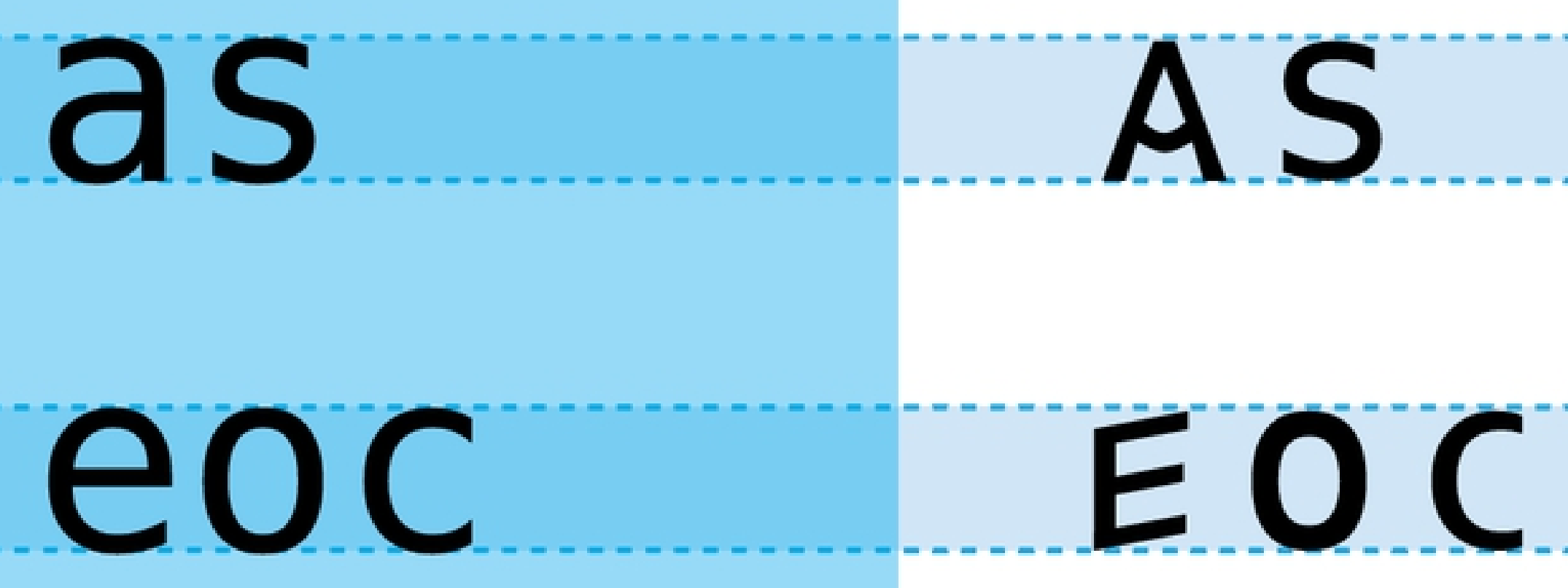

mnu $\quad m n u$

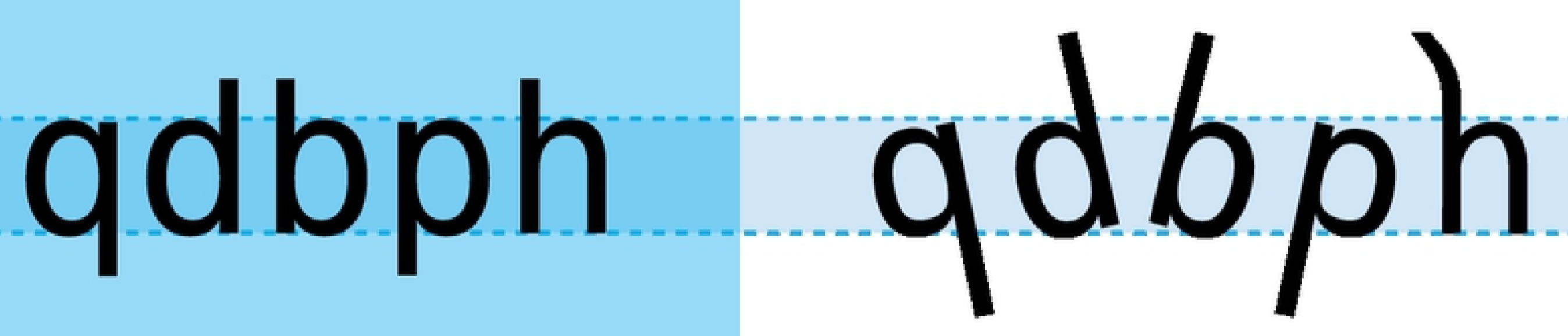

tilfj

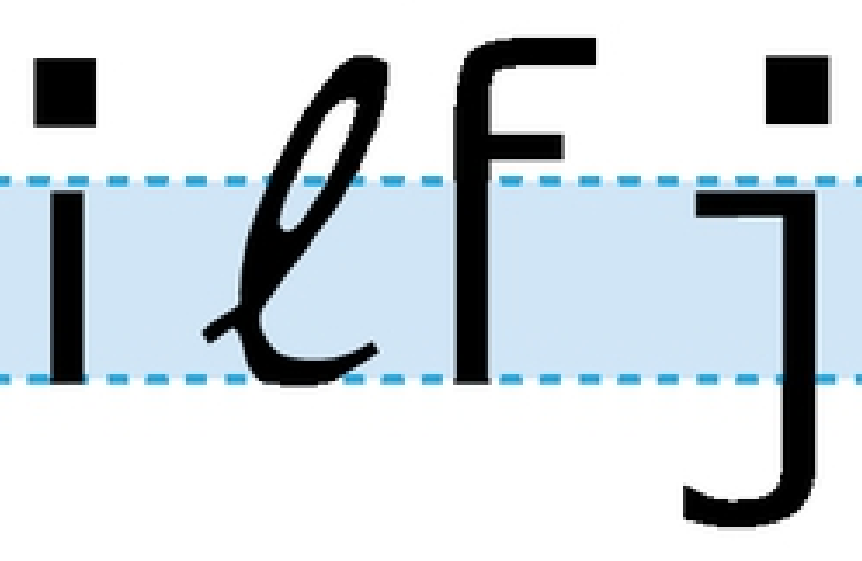

Fig 2 
a the quick brown fox jumps over a lazy dog

secent

(b the quick brown fox jumps over a lazy dog riactiona

C THe quick Brown fox jumps over a lazy dog

salate

d the quick brown fox jumps over a lazy dog

e colet The quick brown fox jumps over a lazy dog

Fig 3 


$$
{ }^{\circ} \mathrm{kap}^{\circ} \mathrm{kap}{ }^{\circ} \mathrm{kap}{ }^{\circ} \mathrm{kap}{ }^{\circ} \mathrm{kap}
$$
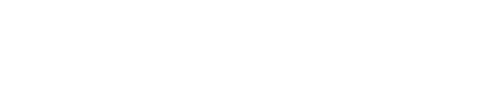


\section{hule \\ 0}

Fig 5

pseudoword

hule

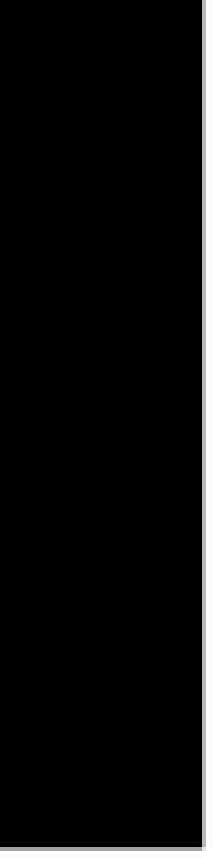

0

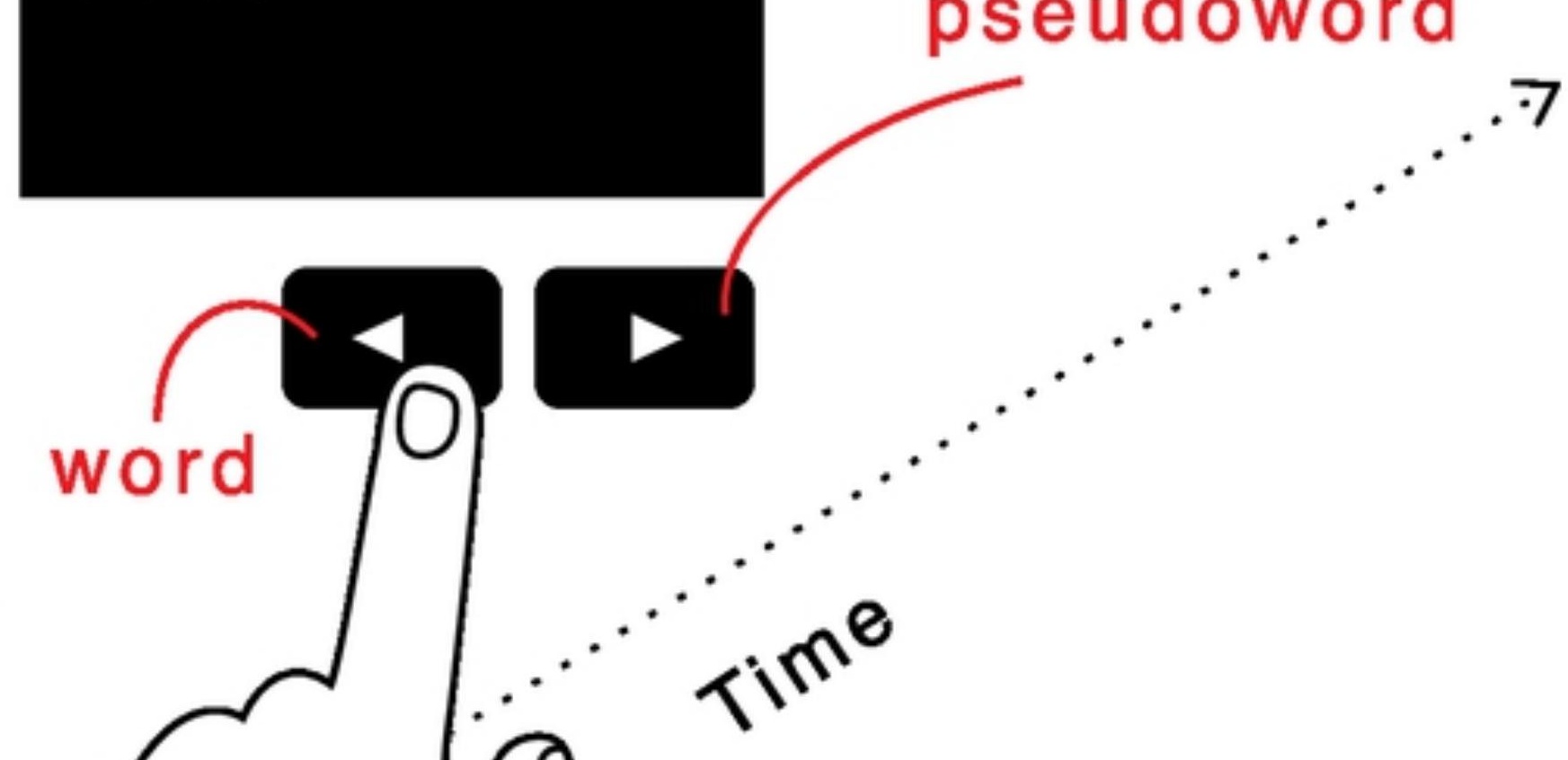


Experiment 1. Lexical decision

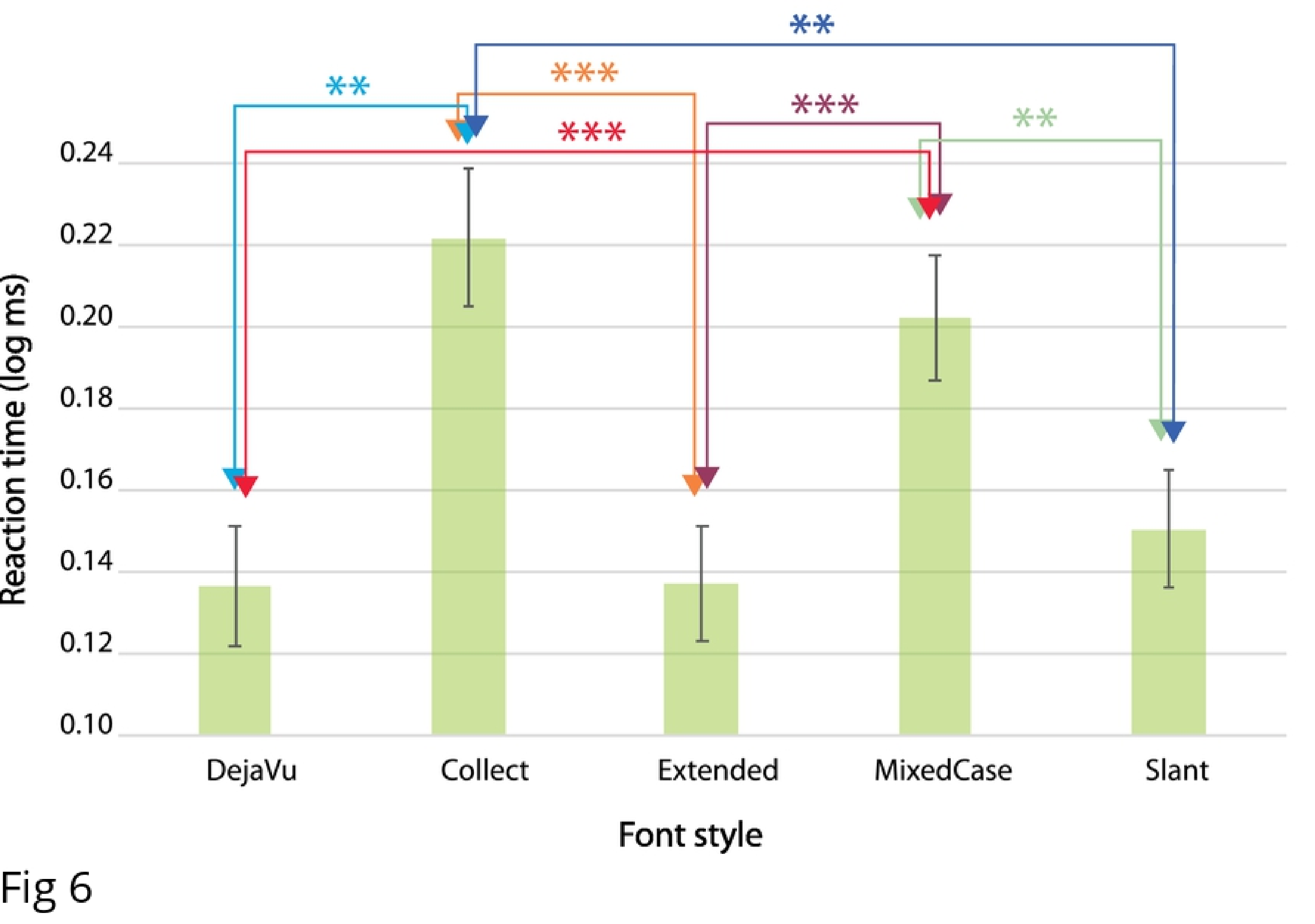




\section{○}

lefghijklm grstuvwyz

ihf

Fig 7 
Experiment 2. Trigram recognition

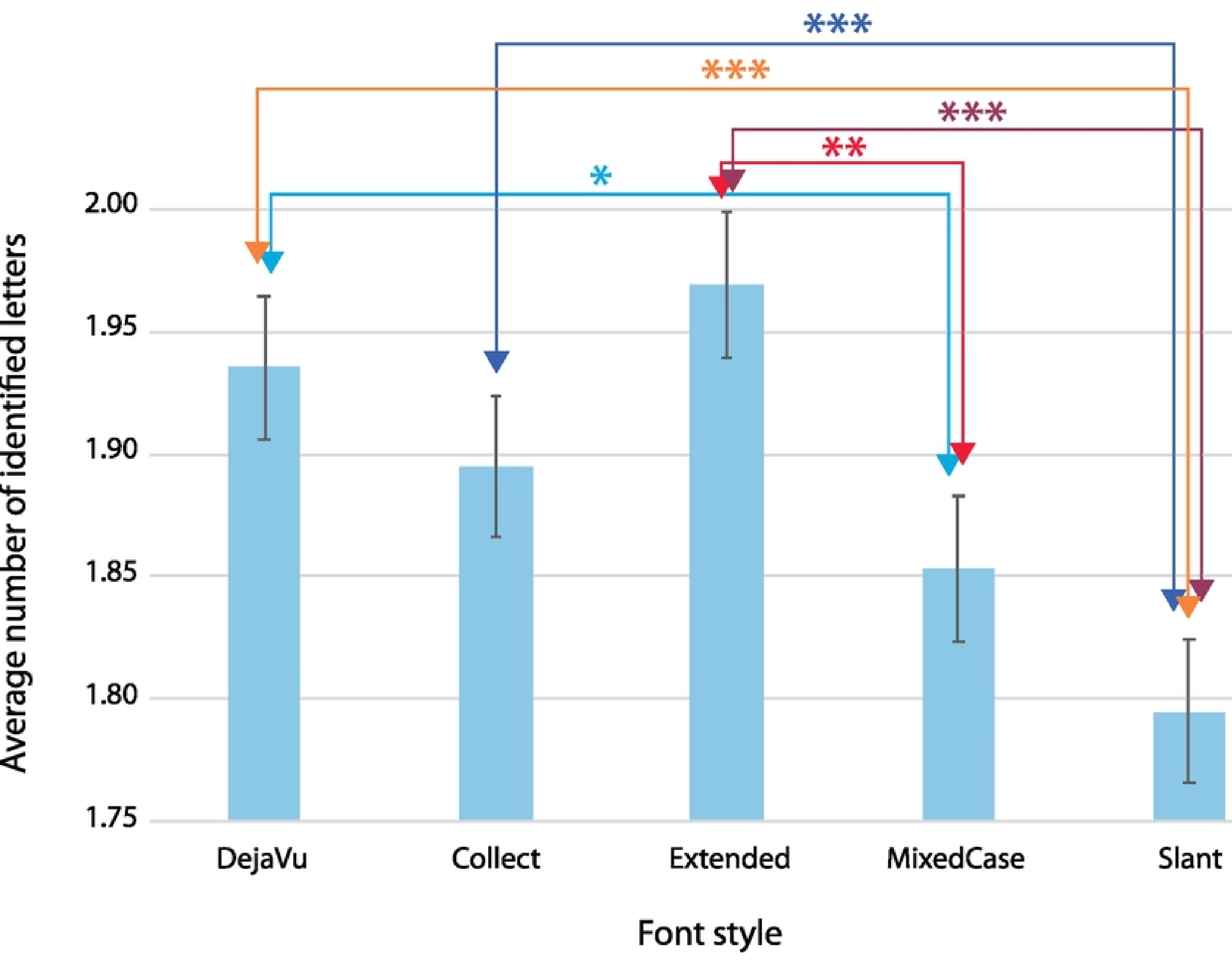

Fig 8 